30. Аралбаев Н.К. Флора Зайсанской котловины, ее анализ и генезис: автореф. дис. ... д-ра биол. наук. Алматы, 1997. $58 \mathrm{c.}$

31. Сагателян А.А. Классификация географических элементов флоры Армении // Ботанический журнал. 1997. Т. 82, № 9. С. 25-38.

32. Стрельникова Т.О. Флора Бащелакского хребта: автореф. дис. ... канд. биол. наук. Томск: ТГУ, 2002. $22 \mathrm{c}$.

33. Стрельникова Т.О. Анализ географической структуры флоры Бащелакского хребта // Бот. иссл. Сибири и Казахстана. 2003. № 9. С. 51-57.

34. Науменко Н.И. Флора Южного Зауралья: автореф. дис. ... д-ра биол. наук. СПб.: СПбГУ, 2003. $32 \mathrm{c}$.

35. Рябовол С.В., Антипова Е.М. Хорологическая структура флоры г. Красноярска // Вестник КрасГАУ (Красноярского государственного аграрного университета). 2008. № 2. С. 119-127.

36. Портениер Н.Н. Методические вопросы выделения географических элементов флоры Кавказа // Бот. журн. 2000. Т. 85, № 6. С. 76-84.
37. Портениер Н.Н. Системы географических элементов флоры Кавказа // Бот. журн. 2000. Т. 85, № 9. C. 26-33.

38. Тахтаджян А.Л. Флористические области Земли. Л.: Наука, 1978. 247 с.

39. Камелин Р.В. Важнейшие особенности сосудистых растений и флористическое районирование России // Проблемы ботаники Южной Сибири и Монголии. Барнаул: Изд-во АзБука, 2002. С. 36-41.

40. Лавренко Е.М. О принципах ботанико-географического расчленения Палеарктики // Бот. журн. 1948. № 1 .

41. Антипова Е.М. Растительность северных лесостепей Средней Сибири. Красноярск: КГПУ, 2016. $300 \mathrm{c}$.

42. Тахтаджян А.Л. Происхождение и расселение цветковых растений. Л.: Наука, 1970. 145 с.

43. Hayek A. Allgemeine Pflanzengeographie. Berlin, 1926. $409 \mathrm{~s}$.

44. Good R. The geography of the flowering plantz. London, 1947. 403 p.

45. Zohary M. Geobotanical foundations of the Middle East. Amsterdam, 1973. Vol. 1-2. 739 p.

\title{
THE EURO-SIBERIAN GEOGRAPHICAL ELEMENT FLORA STRUCTURE OF THE MIDDLE SIBERIA FOREST-STEPPES
}

(C) 2018

Antipova Ekaterina Mikhailovna, doctor of biological sciences, professor of Biological and Ecological Department Krasnoyarsk State Pedagogical University named after V.P. Astafiev (Krasnoyarsk, Russian Federation)

Abstract. The structure of geographical (arealogical) elements is one of the most important flora characteristics, because genetic composite groups are established on the basics of generic and species areas analysis and regularities of flora formation are determined. The object of the research is a complete species composition of vascular plants, revealed within the boundaries of the researched forest-steppes - Krasnoyarsk, Kansk and Achinsk (Krasnoyarsk Region). The North forest-steppes flora was detected by the specific flora method established by A.I. Tolmachev. The aim of this work is to summarize materials of the Euro-Siberian geographical element flora structure in the North forest-steppes ecosystems of the Middle Siberia with the characteristics of geographical elements selected on the basis of the fitohorions concept. It is based on the accordance principle of species distribution to natural (Botanical-geographical) zoning of the Earth. To determine the areas we used modern planetary floristic zoning established by A.L. Takhtajan with some amendments: floristic zoning by L.I. Malyshev was taken into account to Siberia, etc., the Russian Far East - by R.V. Camelin. As a result of the work geographical elements of the boreal group were assigned: Circumboreal (133 species, 9,6\% of the whole flora), Eurosiberian (384 species, 27,7\%), Pontic-South Siberian (81 species, $5,85 \%)$, Siberian (154 species, $11,12 \%)$.

Keywords: north forest-steppes; forest-steppes ecosystems; flora; Middle Siberia; system of fitohorions; geographical element; horological group; types of areas; boreal group; local flora; floral zoning; Circumboreal; Eurosiberian; Pontic-South Siberian; Siberian; Holarctic.

УДК $574.24: 581.192$

Статья поступила в редакцию 05.12.2017

\section{ОСОБЕННОСТИ АККУМУЛЯЦИИ ТЯЖЕЛЫХ МЕТАЛЛОВ ЛИСТЬЯМИ ПОДОРОЖНИКА БОЛЬШОГО (PLANTAGO MAJOR L.) В УСЛОВИЯХ УРБАНИЗИРОВАННЫХ ТЕРРИТОРИЙ}

(C) 2018

Бабкина Людмила Александровна, кандидат биологических наук, доцент кафедры общей биологии и экологии

Лукьянчиков Дмитрий Сергеевич, магистрант кафедры общей биологии и экологии Лукьянчикова Оксана Владимировна, кандидат биологических наук, доцент кафедры общей биологии и экологии

Курский государственный университет (г. Курск, Российская Федераџия)

Аннотация. Рассматривается содержание подвижных форм цинка, кадмия и свинца в почве участков с разным уровнем техногенного воздействия и особенности накопления тяжелых металлов листьями подорожника большого Plantago major L. Почвы промышленной зоны характеризуются загрязнением соединениями свинца и кадмия. Содержание ионов свинца и цинка в листьях подорожника большого $P$. major, произраста- 
ющего на данном участке, превышает допустимые значения. Экологически безопасным является растительный материал, собранный в окрестностях города вблизи лесного массива. По возрастанию аккумулирующей способности тяжелые металлы располагаются в порядке: свинец < кадмий < цинк, что отражает степень их важности для растений и сходство физико-химических показателей. Более высокие значения коэффициентов накопления для кадмия по сравнению со свинцом связаны с его транслокацией в клетки переносчиками для биофильного элемента цинка. Увеличение содержания в почве цинка и кадмия приводит к снижению аккумуляции этих ионов в листьях. Свинец поступает в листья подорожника большого P. major как через корневую систему из почвы, так и через устьичный аппарат эпидермиса листа из воздуха.

Ключевые слова: подорожник большой; Plantago major L.; подвижные формы тяжелых металлов; цинк; кадмий; свинец; урбанизированные территории; атомно-адсорбционный анализ; предельно допустимая концентрация (ПДК); индекс суммарной токсической нагрузки; коэффициент накопления; аккумулирующая способность; коэффициент ранговой корреляции Спирмена.

\section{Введение}

Актуальной проблемой современности является накопление загрязняющих веществ в различных компонентах окружающей среды. Основными источниками тяжелых металлов в почве являются транспорт и промышленность. Поступая в почву, тяжелые металлы способны мигрировать с током воды в растения и аккумулироваться в них. Особую опасность создает накопление тяжелых металлов в лекарственных растениях. Расширение площади городских территорий, низкая экологическая грамотность населения являются предпосылками сбора лекарственного сырья населением для применения в домашних условиях в черте города, в связи с чем практическую значимость приобретает оценка содержания тяжелых металлов в фитомассе и изучение способности к их накоплению у различных растений.

Аккумулирующая способность лекарственных растений по отношению к тяжелым металлам изучалась различными авторами. Установлено, что поглощение тяжелых металлов лекарственными растениями происходит избирательно [1-3]. Так, листья подорожника большого обладают высокой способностью накапливать из почвы ионы кадмия, меди, цинка, хрома и кобальта, в то время как трава горца птичьего характеризуется незначительной концентрирующей способностью [4; 5]. Среднее содержание тяжелых металлов в надземной части растений тысячелистника обыкновенного убывает в ряду: $\mathrm{Fe}>\mathrm{Mn}>\mathrm{Zn}>\mathrm{Cu}>\mathrm{Pb}>\mathrm{Ni}>\mathrm{Cd}>\mathrm{Co}$ [6]. В траве горца птичьего и пижмы обыкновенной биотопов Казани наиболее интенсивно накапливались $\mathrm{Zn}, \mathrm{Cu}$ и $\mathrm{Cr}$. Горец птичий характеризуется хорошей аккумулирующей способностью по отношению к железу, никелю и хрому, а пижма обыкновенная - к меди [7]. Накопление ртути в лекарственных растениях происходит только при техногенном воздействии [8]. Вегетативные органы растений поглощают тяжелые металлы с различной интенсивностью. Так, в стеблях тысячелистника в меньшей степени накапливаются соединения меди, никеля и свинца, в листьях - цинка. В то же время высокая концентрация цинка характерна для соцветий [9].

Целью представленной работы явилось изучение особенностей накопления тяжелых металлов листьями подорожника большого Plantago major L., произрастающего в урбанизированных условиях с разной степенью техногенного загрязнения почв.

Цинк, свинец, кадмий являются приоритетными загрязнителями урбаноземов г. Курска и его окрестностей [10]. Несмотря на их различную биологическую значимость для живых организмов, данные тяжелые металлы по степени опасности для контроля загрязнения и прогноза состоянии почв относятся к 1 классу (высокоопасные) [11]. Содержание подвижных форм тяжелых металлов в почве и листьях подорожника большого P. major изучали на участках г. Курска и его окрестностей с разной степенью техногенного воздействия (рис. 1).

\section{Методика исследований}

Отбор образцов почвы на каждом участке осуществляли в нескольких точках на глубину $10 \mathrm{~cm}$, исходя из того, что в данном горизонте располагается корневая система подорожника большого P. major и происходит преимущественное накопление загрязнителей. Путем смешивания единичных проб почвы, отобранных в разных точках пробной площадки, составляли единую пробу, которую использовали для анализа $[12 ; 13]$. Подорожник большой P. major является доминирующим видом в естественном растительном сообществе (участок 1), так и в урбанизированных фитоценозах (участки 2-4). Листья данного растения являются лекарственным сырьем и могут использоваться населением. Подорожник большой $P$. major характеризуется высокими пороговыми концентрациями и обладает значительной аккумулирующей способностью по отношению к тяжелым металлам [5], что является предпосылкой для проведения анализа.

Растительные образцы получали путем сбора листовых пластинок по одной от каждого растения $(\mathrm{n}=25)$ в июле с последующим их высушиванием и измельчением. Содержание цинка, свинца и кадмия в почвенных и растительных образцах определяли атомно-адсорбционным методом с использованием анализатора «Спектр-5» [14; 15$]$.

Для оценки общего уровня загрязнения почв использовали индекс суммарной токсичной нагрузки $\mathrm{S}_{\mathrm{i}}[16]$.

В настоящее время отсутствуют нормативные документы, регламентирующие содержание тяжелых металлов в лекарственном сырье, что создает определенные трудности при оценке его экологической безопасности. Различными авторами применяются ПДК для биологически активных веществ к пище на растительной основе [4], для кормов сельскохозяйственных животных [6]. Для оценки содержания в листьях подорожника большого P. major кадмия и свинца руководствовались ОФС 1.5.3.0009.15 Определение содержания тяжелых металлов и мышьяка в лекарственном растительном сырье и лекарственных растительных препаратах [14], цинка - требованиями СанПин 2.3.2.1078-01 Продовольственное сырье и пищевые продукты. Гигиенические требования безопасности и пищевой ценности пищевых продуктов к БАВ к пище на растительной основе [17]. 


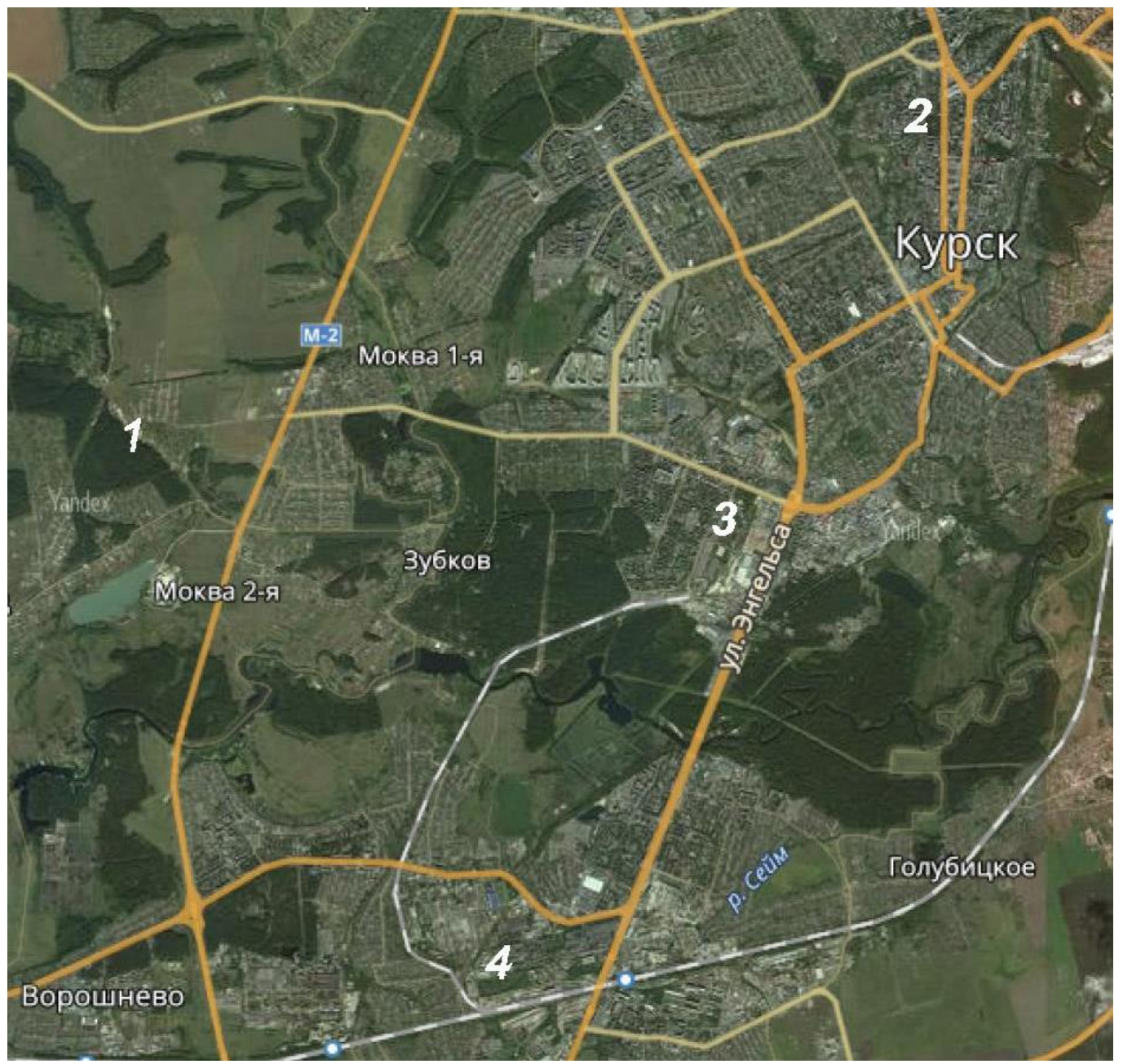

Рисунок 1 - Точки отбора образцов почвы и растительного материала: 1 - окрестности г. Курска (вблизи лесного массива, контроль); 2- парк Героев Гражданской войны (рекреационная зона); 3- парк КЗТЗ (рекреационная зона); 4- пос. Аккумулятор (промышленная зона)

Взаимосвязь между содержанием подвижных форм цинка, кадмия и свинца в почве и их количеством в листьях подорожника большого P. major оценивали с помощью непараметрического коэффициента ранговой корреляции Спирмена [18, с. 238 244]. Статистически значимые показатели ранговой корреляции свидетельствуют о преимущественном поступлении тяжелых металлов в растения из почвы. Слабая корреляционная зависимость между содержанием веществ в почве и растительных образцах говорит о поступлении загрязнителей через устьичный аппарат растений [4].

\section{Результаты исследования и их обсуждение}

Анализ содержания подвижных форм тяжелых металлов в почвах исследуемых участков показал (табл. 1), что концентрация цинка варьирует от 2,54 мг/кг (парк Героев Гражданской войны) до 19,77 мг/кг (парк КЗТЗ); концентрация свинца - от 2,45 мг/кг (парк Героев Гражданской войны) до 302,90 мг/кг (пос. Аккумулятор); концентрация кадмия - от 0,09 мг/кг (парк КЗТЗ) до 12,29 мг/кг (пос. Аккумулятор).

Сравнение содержания подвижных форм цинка, кадмия и свинца с гигиеническими нормативами [19] выявило превышение для свинца в почвах парка КЗТЗ и в промышленной зоне, что, возможно, связано с расположением участков вблизи автомагистра- лей в промышленной части города. Незначительное отклонение от регионального фона отмечено для кадмия на территории парка Героев Гражданской войны, значительное загрязнение почв наблюдается в промышленной зоне (участок 4). Концентрация подвижных форм цинка в почвах всех исследуемых участков соответствует допустимым значениям. Учитывая неоднозначное загрязнение почв тяжелыми металлами был рассчитан индекс суммарной токсичной нагрузки $\left(\mathrm{S}_{\mathrm{i}}\right)$ на почвы изучаемых территорий и проведено их ранжирование по степени возрастания показателя: окрестности г. Курска (контроль) $(1,0$ отн. ед.) < парк Героев Гражданской войны $(1,28$ отн. ед) < парк КЗТЗ (3,89 отн. ед) < пос. Аккумулятор (79,03 отн. ед).

В результате анализа содержания тяжелых металлов в листьях подорожника большого P. major установлено, что экологически безопасным является растительный материал, собранный в лесном массиве и в парковой зоне центральной части города (парк Героев Гражданской войны). В фитомассе подорожника большого P. major пос. Аккумулятор накапливается значительное количество свинца (20,47 ПДК) и отмечается небольшое превышение нормативов для цинка (1,05 ПДК). В растениях, произрастающих в парке КЗТЗ, зафиксировано максимальное количество цинка по сравнению с другими участками (табл. 1). 
Бабкина Л.А., Лукьянчиков Д.С., Лукьянчикова О.В.

Особенности аккумуляции тяжелых металлов листьями подорожника..

03.02.00 - общая биология

Таблица 1 - Содержание подвижных форм тяжелых металлов в почвах исследуемых участков и листьях подорожника большого P. major

\begin{tabular}{|l|c|c|c|}
\hline \multirow{2}{*}{ Участок } & \multicolumn{3}{|c|}{ Содержание тяжелых металлов, мг/кг } \\
\cline { 2 - 4 } & $\mathrm{Pb}^{2+}$ & $\mathrm{Cd}^{2+}$ & 3,06 \\
\hline \multirow{2}{*}{ Окрестности г. Курска (контроль) } & 2,98 & 0,10 & $41,54 \pm 5,15$ \\
\cline { 2 - 4 } & $0,89 \pm 0,09$ & $0,12 \pm 0,01$ & 19,77 \\
\hline \multirow{2}{*}{ Парк КЗТ3 } & $12,68^{*}$ & 0,09 & $73,14 \pm 7,31^{2+}$ \\
\hline \multirow{2}{*}{ Парк Героев Гражданской войны } & $1,55 \pm 0,16$ & $0,11 \pm 0,01$ & 2,54 \\
\cline { 2 - 4 } & 2,45 & $0,22^{*}$ & $18,27 \pm 9,17$ \\
\hline \multirow{2}{*}{ Район завода «Аккумулятор» } & $3,61 \pm 0,36$ & $0,13 \pm 0,01$ & $52,73 \pm 5,27 *$ \\
\hline \multirow{2}{*}{ ПДК } & $302,90^{*}$ & $0,87 \pm 0,09$ & 23 \\
\hline
\end{tabular}

Примечание. Верхняя строка - содержание тяжелых металлов в почве, нижняя строка - содержание тяжелых металлов в листьях растений; * - превышение допустимых нормативов.

Особенности аккумулирующей способности листьев подорожника большого P. major по отношению к цинку, кадмию и свинцу отражает коэффициент накопления $\left(\mathrm{K}_{\mathrm{H}}\right)$ (табл. 2), который представляет собой отношение содержания вещества в растении к концентрации его подвижной формы в почве. Значения $\mathrm{K}_{\mathrm{H}}<1$ свидетельствуют о наличии корневого барьера при транслокации тяжелого металла в растительный организм. При $\mathrm{K}_{\mathrm{H}}>1$ происходит беспрепятственное поступление токсикантов [5].

Таблица 2 - Коэффициенты накопления тяжелых металлов листьями подорожника большого P. major в зависимости от уровня суммарной токсической нагрузки на почвы

\begin{tabular}{|l|c|c|c|c|}
\hline \multirow{2}{*}{\multicolumn{1}{c|}{ Участок }} & $\begin{array}{c}\text { Индекс суммарной } \\
\text { токсической нагрузки } \mathrm{S}_{\mathrm{i}},\end{array}$ & \multicolumn{3}{|c|}{$\begin{array}{c}\text { Коэффициент накопления К } \\
\text { тяжелых металлов }\end{array}$} \\
\cline { 3 - 6 } & отн. ед & $\mathrm{Pb}^{2+}$ & 1,20 & 13,58 \\
\hline Окрестности г. Курска (контроль) & 1,00 & 0,30 & 0,59 & 16,24 \\
\hline Парк Героев Гражданской войны & 1,28 & 1,47 & 1,22 & 3,70 \\
\hline Парк КЗТЗ & 3,89 & 0,12 & 0,07 & 2,84 \\
\hline Район завода «Аккумулятор» & 79,03 & 0,41 & $\mathrm{Cd}^{2+}$ \\
\hline
\end{tabular}

При увеличении содержания подвижной формы происходит снижение коэффициента накопления, что свидетельствует о включении механизмов, ограничивающих поступление тяжелых металлов в надземную часть растений. Однако высокие концентрации металла в почве приводят к нарушению барьерной функции, что сопровождается возрастанием его миграции в ткани растения и увеличению $K_{\mathrm{H}}[5 ; 20]$. Анализ аккумулирующей способности свинца листьями подорожника большого показал, что в условиях низкого содержания металла в почве контрольного участка происходит его незначительное накопление в листьях $\left(\kappa_{\mathrm{H}}=0,30\right)$ в силу низкой биофильности и наличия барьеров на этапах поступления почва растение, подземная часть растения - надземная часть растения. Однако при сопоставимом количестве свинца в почвах парка Героев Гражданской войны значительно возрастает его накопление в листьях подорожника большого P. major $\left(\mathrm{K}_{\mathrm{H}}=1,47\right)$, что, возможно, связано с дополнительным поступлением через листовую поверхность. На участке, характеризующемся превышением нормативов содержания свинца в почве в 2 раза (парк КЗТЗ), отмечается снижение коэффициента накопления $\left(\kappa_{\mathrm{H}}=0,12\right)$. При возрастании загрязнения почв свинцом (пос. Аккумулятор) наблюдается рост коэффициента накопления $(0,41)$ по сравнению с контролем, что, возможно, связано с нарушением клеточных барьерных механизмов. Аккумуляция ионов кадмия в листьях подорожника большого P. major снижается при увеличении содержания его подвижных форм в почве. При этом в условиях существенного загрязнения почв данным металлом он практически не накапливается в листьях, однако при допустимых концентрациях в почве отмечается отсутствие корневых барьеров и усиление транслокации в надземную часть растений. Кадмий и свинец не относятся к биогенным элементам для растений. Сравнение коэффициентов накопления этих металлов для растений контрольного участка показывает, что кадмий легче поглощается листьями подорожника большого P. major по сравнению со свинцом. Это может быть связано с тем, что из окружающей среды ионы кадмия попадают в клетку через переносчики железа или цинка, относящиеся к ZIP семейству, а также через кальциевые каналы. В ксилемном транспорте из корневой системы в надземную часть растения участвуют как для цинка, так и для кадмия белки HМА2 и HMA4 ceмейства АТФаз тяжелых металлов. Семейство белков CDF также играет роль в транспорте как цинка, так и кадмия [21]. При изучении аккумулирующей способности листьев подорожника большого P. major по отношению к цинку установлено, что цинк, являясь биофильным элементом, может значительно накапливаться в надземной фитомассе ввиду отсутствия барьерных систем. Однако возрастание количества подвижных форм цинка в почве приводит к ограничению его поступления в листья растения. Анализ значений коэффициента накопления свидетельствует о значительной способности листьев подорожника большого P. major накапливать цинк, в меньшей степени кадмий и свинец. Коэффи- 
Бабкина Л.А., Лукьянчиков Д.С., Лукьянчикова О.В.

циент накопления отражает степень биофильности тяжелого металла [6]. Таким образом, поступление из почвы тяжелых металлов в растения зависит не только от содержания подвижных форм, но и от биологической значимости иона для организма.

Корреляционный анализ с помощью непараметрического коэффициента ранговой корреляции Спирмена между содержанием подвижных форм цинка, кадмия и свинца в почве и их количеством в листьях подорожника большого P. major выявил, что концентрация цинка и кадмия в листьях подорожника большого P. major определяется количеством в почве их подвижных форм $(\mathrm{P}=1)$. Коэффициент ранговой корреляции для свинца, равный 0,4 при статистически значимом показателе 0,94 , свидетельствует о поступлении свинца в листья как путем миграции через корневую систему, так и посредством диффузии через устьичный аппарат.

\section{Выводы}

Листья подорожника большого $P$. major обладают хорошей аккумулирующей способностью по отношению к цинку, в меньшей степени к кадмию. Источниками ионов свинца в листовых пластинках могут быть как почвенные ионы, так и атмосферные загрязнители. Увеличение содержания подвижных форм тяжелых металлов в почве до определенных концентраций приводит к снижению коэффициента накопления. Однако значительные загрязнения почвы тяжелыми металлами способствуют беспрепятственной миграции в надземную часть и аккумулированию токсикантов в больших количествах. Использование листьев подорожника большого P. major для заготовки лекарственного сырья экологически безопасно только в окрестностях г. Курска. В рекреационных зонах в черте города существует риск накопления тяжелых металлов выше допустимых значений. Лекарственные растения, собранные в промышленной зоне города, создают угрозу здоровью.

\section{Список литературы:}

1. Гравель И.В. Необходимость оценки безопасности лекарственного растительного сырья по содержанию экотоксикантов // Ведомости научного центра экспертизы средств медицинского применения. 2012. № 2. С. 37-39.

2. Трубина М.Р., Воробейчик Е.Л. Содержание тяжелых металлов в лекарственных растениях в зоне аэротехногенного воздействия Среднеуральского медеплавильного завода // Растительные ресурсы. 2013. T. 49, № 2. C. 203-222.

3. Трубников В.В., Злобина Ю.М., Федосова И.В. Закономерность распределения микроэлементов-биофилов и тяжелых металлов в системе почва-растение в урбанизированной среде // Известия Оренбургского государственного аграрного университета. 2013. № 4 (42). C. 211-213.

4. Великанова Н.А., Гапонов С.П., Сливкин А.И. Оценка экологического состояния почв и лекарственного растительного сырья (травы горца птичьего и листьев подорожника большого) по содержанию тяжелых металлов в городе Воронеже и его окрестностях // Вестник ВГУ. Серия: Химия. Биология. Фармация. 2012. № 2. С. 238-244.

5. Жуйкова Т.В., Зиннатова Э.Р. Аккумулирующая способность растений в условиях техногенного загрязнения почв тяжелыми металлами // Поволжский экологический журнал. 2014. № 2. С. 196-207.
6. Семенова И.Н., Рафикова Ю.С., Биктимерова Г.Я., Суюндуков Я.Т. Содержание биоэлементов в лекарственных растениях в зоне воздействия отработанного карьера (на примере поселка Тубинский республики Башкортостан) // Микроэлементы в медицине. T. 18, № 1. 2017. С. 43-51.

7. Елагина Д.С., Архипова Н.С., Сибгатуллина М.Ш., Рязанов М.С. Содержание тяжелых металлов в горце птичьем и пижме обыкновенной в условиях урбанизированных территорий // Вестник ВГУ. Серия: Химия. Биология. Фармация. 2017. № 1. С. 57-66.

8. Великанова Н.А., Гапонов С.П., Сливкин А.И. Изучение динамики накопления тяжелых металлов травой горца птичьего и листьями подорожника большого в процессе вегетации в городе Воронеже и его окрестностях // Современные проблемы науки и образования. 2012. № 5. С. 294.

9. Семенова В.В., Магомедалиев 3.Г. Влияние экологических факторов на содержание некоторых тяжелых металлов в Achillea millefolium L. // Юг России: экология, развитие. 2009. № 2. С. 46-49.

10. Прусаченко А.В. Экотоксикологическая оценка загрязнений тяжелыми металлами урбаноземов города Курска: автореф. дис. ... канд. биол. наук. М., 2011. $19 \mathrm{c}$.

11. ГОСТ 17.4.1.02-83 Охрана природы (ССОП). Почвы. Классификация химических веществ для контроля загрязнения.

12. ГОСТ 17.4.3.01-83 Охрана природы. Почвы. Общие требования к отбору проб.

13. ГОСТ 17.4.4.02-84 Охрана природы. Почвы. Методы отбора и подготовки проб для химического, бактериологического, гельминтологического анализа.

14. ОФС 1.5.3.0009.15 Определение содержания тяжелых металлов и мышьяка в лекарственном растительном сырье и лекарственных растительных препаратах.

15. РД 52.18.289-90 Методические указания. Методика выполнения измерений массовой доли подвижных форм металлов (меди, свинца, цинка, никеля, кадмия, кобальта, хрома, марганца) в пробах почвы атомно-абсорбционным анализом.

16. Жуйкова Т.В. Реакция ценопопуляций и травянистых сообществ на химическое загрязнение среды: автореф. дис. ... д-ра биол. наук. Екатеринбург. 2009. $40 \mathrm{c}$.

17. СанПин 2.3.2.1078-01 Продовольственное сырье и пищевые продукты. Гигиенич. требования безопасности и пищевой ценности пищевых продуктов. Санитарно-эпидемиологические правила и нормативы.

18. Лакин Б.Ф. Биометрия. М.: Высшая школа, 1990. $112 \mathrm{c}$

19. ГН 2.1.7.2041-06. Предельно допустимые концентрации (ПДК) химических веществ в почве.

20. Бабкина Л.А., Миронов С.Ю., Тригуб Н.И., Прусаченко А.В., Поздняков В.А. Влияние ионов свинца на содержание фотосинтетических пигментов в растениях ячменя обыкновенного // Эколого-географические проблемы регионов России: мат-лы VI всерос. науч.-практ. конф. 15 января 2015 г., Самара / отв ред. И.В. Казанцев. Самара: ПГСГА, 2015. С. 19-24.

21. Кулаева О.А., Цыганов В.Е. Молекулярно-генетические основы устойчивости высших растений к кадмию и его аккумуляции // Экологическая генетика. 2010. T. VIII. № 3. С. 3-15. 


\title{
PECULIARITIES OF HEAVY METALS ACCUMULATION BY DOORYARD PLANTAIN'S LEAVES (PLANTAGO MAJOR L.) IN THE URBANIZED TERRITORIES
}

(C) 2018

Babkina Lyudmila Alexandrovna, candidate of biological sciences, associate professor of General Biology and Ecology Department

Lukyanchikov Dmitry Sergeevich, master student of General Biology and Ecology Department

Lukyanchikova Oksana Vladimirovna, candidate of biological sciences, associate professor of General Biology and Ecology Department Kursk State University (Kursk, Russian Federation)

\begin{abstract}
The paper reveals the content of extractable zinc, cadmium and lead in the soil of the territories with different level of technological influence. The peculiarities of heavy metals storage by dooryard plantain's leaves Plantago major L. are observed. The soils of the industrial zone are characterized by pollution with cadmium and lead compounds. The content of lead and zinc ions in dooryard plantain's leaves $P$. major, growing in this region, oversteps the accepted values. The plant material picked in the suburbs of the city close to the forest zones is ecologically safe. According to increasing of accumulation features, heavy metals are located in the following order: lead < cadmium < zinc that reflects the degree of their importance for plants and the similarity of their physical and chemical indexes. The higher indexes of the storage coefficients for cadmium in comparison with lead are connected with its translocation into cells by carriers for zinc biophile element. The increase of zinc and cadmium content in the soil leads to decrease of accumulation of these ions in leaves. Lead gets into dooryard plantain's leaves $P$. major from both through roots from the soil and through mouth apparatus of leaf epidermis from the air.

Keywords: dooryard plantain; Plantago major L.; extractable heavy metals; zinc; cadmium; lead; urbanized territories; atomic absorption analysis; maximum allowable concentration (MAC); index of total toxin burden; accumulation coefficient; accumulation capacity; range correlation coefficient by Spirment.
\end{abstract}

УДК 574.58

Статья поступила в редакцию 26.11.2017

\section{ЗАРАЖЕННОСТЬ ПОПУЛЯЦИИ VIVIPARUS VIVIPARUS L. РЕКИ МАЛАЯ КОКШАГА ПАРТЕНИТАМИ ТРЕМАТОД И СОДЕРЖАНИЕ В ТКАНЯХ МОЛЛЮСКОВ КАРОТИНОИДОВ} (C) 2018

Бедова Прасковья Владимировна, кандидат биологических наук, доцент кафедры биологии Марийский государственный университет (г. Йошкар-Ола, Российская Федерация)

Аннотация. В работе представлены результаты многолетних исследований (2001-2011 гг.) популяции Viviparus viviparus L. реки Малая Кокшага, которая является 42-м левым притоком реки Волга и протекает по территории Республики Марий Эл. Для данной популяции изучена плотность, биомасса, половая структура и возрастная структура. Проведено определение зараженности гастропод партенитами трематод и изучено влияние паразитов на содержание каротиноидных пигментов в тканях моллюсков. Для определения интенсивности инвазии разработана трехбалльная шкала зараженности. На протяжении всего периода исследований зараженность $V$. viviparus партенитами трематод была стабильно высокой. Более $50 \%$ всех особей были заражены личинками различных трематод на всех стадиях развития. Существенных различий в зараженности самцов и самок не зарегистрировано. Прослеживается влияние трематодной инвазии на содержание каротиноидов. У зараженных особей обоих полов и в весенний, и в летний период было зарегистрировано более высокое содержание каротиноидов, чем у незараженных. В популяции V. viviparus реки Малая Кокшага преобладали особи годовалого возраста, с высотой раковины 18,0-25,9 мм. Половая структура популяции V. viviparus реки Малая Кокшага стабильна за весь период проведения исследований. Преобладание самцов либо самок в популяции незначительно. В численности и биомассе $V$. viviparus значимых различий по годам не зарегистрировано.

Ключевые слова: Республика Марий Эл; река Малая Кокшага; город Йошкар-Ола; моллюски; гастроподы; лужанка речная; численность; биомасса; половая структура популяции; самцы; самки; возрастная структура популяции; личиночные стадии трематод; промежуточные хозяева; зараженность; каротиноидные пигменты.

\section{Введение}

Представители брюхоногих моллюсков являются обязательным звеном в циклах развития широкого спектра гельминтов, в первую очередь - трематод. Водоемы, населенные гастроподами, представляют потенциальную опасность для животных и человека. Зараженность моллюсков гельминтами может служить важным показателем уровня биологической опасности водных объектов разного назначения [1].

В зараженности моллюсков партенитами трематод существенную роль играют биотические факто- ры. К биотическим факторам относятся плотность популяции самих моллюсков, других водных беспозвоночных, выполняющих роль промежуточных хозяев трематод, концентрация и видовой состав позвоночных, служащих для трематод дефинитивными хозяевами, и, наконец, характер растительного биоценоза водоемов [2]. Первые сведения по трематодофауне моллюсков России встречаются в работах Д.Ф. Синицына, посвященных изучению строения и развития партенит трематод [3]. К.И. Скрябин в своих трудах приводит систематику целого ряда взрос- 